\title{
AN ATTEMPT AT A TYPOLOGICAL INVESTIGATION OF THE ICE MOTIF AS A SYMBOL OF DEATH
}

\author{
Galina Velikova*
}

\begin{abstract}
Prompted by Frye's classification of literary works the present paper embarks on an investigation of the ice motif and its manifestations in a mythological and literary context. It is based on a restricted corpus, yet the survey made proves the recurrent meaning of ice to be a symbol of death and its various other connotations - inherently associated with the primal meaning revealing it in different aspects in the works to be analyzed.
\end{abstract}

Key words: ice motif, manifestations, fixity, non-fixity, antinomies.

\section{Introduction}

The present work investigates the frequency of usage and the various manifestations of the ice motif in the context of mythological and literary history. It proceeds from the assumption that motif is an independent, stable unit, characterized by a constant primal meaning, hardly affected by the nature of the literary work it might be employed in, the genre, the time or the trend it belongs to. In this respect motif is regarded as a thematic fixture in plot as its narrative life, but broader in meaning, therefore more dynamic and free to transform (Nichev, 1986, p. 130).

The study will add to the multiplicity of interpretations to O'Neill's drama "The Iceman Cometh" which is a text initiating and generating various new meanings and readings. It was written by a man "born condemned to be one of those who has to see all sides of a question" (like one of the protagonists in the same play) (O'Neill, 1994, p. 32), who created a world full of ambivalence and ambiguity, who was preoccupied with the archetypal quest for finality but represented it in terms of antithetical absolutes. No wonder the play has been given so many different interpretations in the context of world dramatic tradition.

The present approach to "The Iceman Cometh" was prompted by N. Frye's classification of literary works. According to it the play may be included in the mythos of winter with the recurrent motif of ice, or the iceman in particular, symbolizing death and various other connotations inherently associated with

* Senior Lecturer, PhD at the Department of Foreign Languages and Applied Linguistics, Naval Academy, Varna, Bulgaria; e-mail: galya.velikova@gmail.com 
the primal meaning, such as darkness, hopelessness, chaos, etc. (Frye, 1987, p. 222) Starting from the fact that ice is formally present in the title and given as a key to understanding the whole work by the dramatist himself immediately puts forward the following questions:

- If the principle of homology is applied, how can a typical significative detail (the ice motif in this case) reflect the whole structure of a literary work and be employed in its structural model?

- How does it take up the theme, orchestrate the dramatic action and in what terms?

For lack of space we are going to dwell only on the ice motif and its manifestations here without specifying its usage in the framework of the play.

We should make it clear that the method employed in this investigation proceeds from the assumption that the meeting of a certain statement with another kind of verbal expression results in their interaction and gives rise to new connotations. The conclusions were made upon a restricted corpus of examples, however, they are based on the Barthesian integration principle (Barthes, 1989, p. 7).*

\section{Analysis}

Motif, as one of the basic units of formal organization, was borrowed from Wagnerian musical drama and gradually acquired the status of an independent, stable unit, characterized by a constant primal meaning, hardly affected by the nature of the literary work it might be employed in. The ice motif, for one, recurrent in "The Iceman Cometh" as a symbol of death, is clearly defined, still it reveals itself from different aspects (Todorov, 1985, p. 143)**, thus allowing a complete survey of its fundamental meaning and secondary connotations in a typological plan.

To deduce the meaning of ice we should associate it first with the image of water as an element of transition between different cycles and interpret it as the congelation of the symbolic significance and stultification of the potentialities of water (Cirlot, 2006, p. 156). In this aspect it is usually represented in mythological thinking. It is present in the chthonic myths of Buddhism whose nether world consisted of hot and cold hells. Even more obviously is the image defined in the description of the seventh earth according to the Koran, the sacred book of Muslims: this was Iblis's home surrounded by congealed ice and mortifying

\footnotetext{
* Actually the integration principle according to Barthes has two aspects: structural and more general. Structurally it allows signification to be described in a theoretical plan and discourse to be segmented in an operational plan. At the same time, the semiotic system is delineated in the context of social and historical development.

** The ice motif can be classed as a complex transformation as different parameters are added to it, elucidating it from different angles.
} 
poison. Beyond it was the Inferno enveloped in ever raging flames. Also to be conceived in this respect is the deity of frost together with these of the sun, moon, wind and clouds in the Finno-Ugric religion. Evidently in all of the above quoted instances ice is considered as a fixity, as a rigid dividing line between various dynamic levels.

On a higher level of thinking, however, the image appears in a somewhat specialized distribution - ice as opposed to fire - probably due to the natural human propensity to think in terms of ceaseless alternations which make possible the continued existence of all phenomena and establish a dialogue." So the creation of the world in the Scandinavian cosmological and eschatological myths is due to the interaction of two natural forces - ice and fire. "The cold and heat meet ... to make the earth", and then the so-called Ragnarökkr, the twilight of the gods, will be heralded by a dreadful winter ... in which everything is doomed to destruction ... until fire consumes all" (Brandon, 1970, p. 562).

Like the world it is present in, the ice image seems to be realized in terms of the opposition form versus non-form, fixity versus non-fixity. Let us first explore its fixed manifestations to find its stable projections in an ever-changing universe. Signifying rigidity and solidification ice stands for regularity and precision to such an extent as to symbolize reason, abstract thinking, science (Jobes, 1961, p. 817) - not accidentally Urizen, the deity of cold reason from Blake's mythology, is traditionally depicted by means of Scandinavian imagery - snow, ice, frost, etc. In "The Snows of Kilimanjaro" "the great, high and unbelievably white square top of Kilimanjaro" stands for the sublime, the ideal and the combination of both concepts might be interpreted as a symbol of Truth, of Integrity, even of Immortality (Baker, 1972, p. 191). Hemingway's notion of the ideal is very close to Nietsche's call in "Human, All Too Human" for the "cold Alpine lands, scarce warmed by the autumn sun and loveless". But besides the words "cold" and "loveless" the allusion to the Alpine lands is also revealing as the root "alb" (meaning "white" in geographical names) is, as a rule, related to the light of the supernatural, to the dream-land isles man has lost and to which he returns again and again in his folktales. So, having acquired the connotation of "sacred", white (the Alps) is once again associated with cold, freezing, sublime.

Curious but not unusual is the gravitation of such categories as pain, suffering and hate round the ice image. Thus in Shelley's "Prometheus Unbound" its usage is not only descriptive but also symbolic - the "burning cold" of the chains is suggestive of Prometheus's unbearable suffering while the "crawling glaciers" impart almost a physical sensation of the lifelessness of frozen nature and create a visualized image of death:

The crawling glaciers pierce me with the spears

\footnotetext{
* According to Lotman dialogue is the basis of all signification forming processes (Lotman, 1990, p. 46).
} 
Of their moon freezing crystals, the bright chains

Eat their burning cold into my bones ....

(Shelley, 1981, p. 156)

In a similar context the ice image is associated with a bleeding wound. In " $A$ Midsummer Night's Dream" Shakespeare uses it to convey the physical intensity of pain, prompted by the contrast between "hoary-headed" and "crimson":

Hoary-headed frosts

Fall in the fresh lap of the crimson rose.

(Shakespeare, 2016, p. 1094)

R. Frost develops the image still further. In his poem "Fire and Ice" ice is equivalent to hate and destruction:

But if I had to perish twice

I think I know enough of hate

To say that for destruction ice

Is also great

And would suffice.

(Frost, 1972, p. 508)

He represents the world in terms of two opposing principles and the survival of mankind in choosing between one of them. According to his poetic vision the equivalent of fire, which is desire, is contrasted to ice, i.e. hate, whose logical consequence might be destruction or death. A similar indicative system seems to be employed by the narrator in "The Quest for the Holy Grail" cycle where interpreting an event he assigns the sun and fire to Christ whereas cold and ice to Lucifer (cf. Todorov, 1985, p. 77).

Up to now the stated symbolic connotations of the image culminate in the eschatological notions of people from different historical periods and illustrate different stages of human thinking. The subterranean, the terminal of our existence, is also the place where the Inferno was located, and is therefore inseparable from the idea of Death. According to Christian medieval beliefs ice was a means of punishment for the envious who spent eternity half-submerged in a freezing river (Tokarev, 1980, pp. 37-39). In Dante's "Divine Comedy" the most horrible sinners were frozen in the icy Cocit lake. Right in the middle of the lake stood Lucifer deep submerged in ice. In Swedenborg, one of Sartre's predecessors, hell's fire and ice are both torturing and destructive - if fire stands for impassivity, then ice is related to the startling realization of one's own impasse and horror caused by it (Stoyanov, 1973, p. 147). In his novel "Heinrich von Ofterdingen" Novalis, too, made a contribution to the eschatological line - he represented Arcturus, the archer, who, by shooting the North Star, would herald the end of the world, as a ruler of an ice-bound kingdom in which man and nature slept enchanted. Here the ice image is already an embodiment of 
Evil leading to death and passivity. The sailors in Melville's "Moby Dick" saw it in a similar light. For them the whiteness of snow and the whale is ambiguous, fascinating, mysterious.

Conceived on a purely semantic level as a symbol of chastity the image is further extended, including not only all resultant connotations but also the explicit idea of dormant death. The traditional similes

"as chaste as ice"

(Shakespeare, 2016, p. 2042),

"as chaste as unsunned snow"

(Shakespeare, 2016, p.3011)

signify innocence, purity and intangibility but can also be interpreted as frigidity, coldness and barrenness. Lacking firm delineations ice becomes the opposite of love, sex and life, associated with sterility, frustration and finally death.

Obviously on diverse semantic and structural levels it is realized as the symbolic equivalent of death revealing it in different aspects. Hence all its variations may be identified as a representation of one single motif - the ice motif as a symbol of death.

The inference drawn is valid even though it is based on a restricted number of examples illustrating one side of the opposition form versus non-form. But the universe is a dialectical unity of fire and ice and man has to experience the whole symbolic chain of life: stupor - death - unreality - non-existence in order to find his place in it (Stoyanov, 1973, p. 224). Thus Coleridge's Ancient Mariner, not being aware of the full significance of the world he lived in, had to endure it thrust upon him and conceive the ghostly Life-in-Death as a marriage of two opposite elements, as the dialogue of two voices expressing the extremes of the universe (Beer, 1974, p. 430). Coleridge often illustrated his poetic thought by means of the fire versus ice antinomy, expressed through life and death. The same idea led him to envision the supreme triumph for any creative genius, the creation of a work which would represent in finite terms the indefinite dialectic between the expansive sun and the hardened ice for ever ready to lose or modify its form at the touch of warmth. In a similar way he strove to represent the pleasure dome in "Kubla Khan" as a symbol of art - as a rare miracle combining fundamental oppositions: life and death, or creation and destruction. It is a paradoxical thing,

a miracle of rare device ...,

a sunny pleasure-dome with

caves of ice

(Coleridge, 1981, p. 96) 
where "sunny" stands for the fires of our mind, "the caves of ice" being perhaps related to the cavernous depths of the unconscious. Analogically, the sacred river Alph runs into caverns measureless to man and a sunless sea, i.e. into an infinity of death, only to return to life after that in the "gardens bright".

But blending of the extremes is already a process, not a state, characterized by amorphousness and instability, lack of entities, of clearly defined qualities and dimensions. In this case the ice image signifies the indefinite and unpredictable human relations and becomes symbolic of illusion and uncertainty:

What a sea

of melting ice I walk on.

(Massinger, 1840, p. xxxiii)

The world pictured as the battlefield of opposing principles is the realm of illusion, of doubt and ambiguity. The traditional antinomy between fire and ice, resolved as the blend and marriage of these elements, results in insubstantiality imparted on reality - a typical image of the Elizabethan poets who recorded it. Spenser, for instance:

My love is like to ice, and I to fire ...

What more miraculous thing may be told

That fire which all things melts, should harden ice

And ice which is congested with senseless cold

Should kindle fire by wonderful device.

(Spenser, 1972, p. 36)

The antithesis used here serves more to reveal the miraculous, the unbelievable, which corresponds to the only real wonder in nature - the process of creation - where death and life meet to give dimensions and form to the indefinite and the heterogeneous. Unlike Coleridge Shakespeare envisions and dialectically conceives the situation as Death-in-Life:

Candied with ice, caudle thy morning taste

(Shakespeare, 2016, p.2482)

which is implied by the association of the ice image with candy, i.e. food, and respectively life. For him they are not only intermingled but co-existent, interchangeable, as well. The ability of ice to form and be formed is an impulse to be found in all life. It fascinates and threatens, and is instinctively humanized. Hence, the next stage in the development of the image is personification. For Coleridge there was life in "the secret ministry of frost". So in "The Ancient Mariner",

The ice was here, the ice was there,

The ice was all around,

It cracked and growled, and roared and howled 
Like noises in a swound.

(Coleridge, 1981, p. 73)

ice is animated, omnipresent and omnipotent, like a god. Ever-lasting, aggressive, it is part of a personified nature alien to man which strives to destroy him. The idea reaches its climax in the iceman figure who retains the hostile attitude to man and becomes identifiable with Death, thus signifying the final resignation with the inevitable end.

\section{Conclusions}

Obviously realized on various semantic and structural levels the ice motif leads to and includes different manifestations of its primary meaning - no matter whether directly or figuratively. Represented in finite terms in an indefinite universe it comes to signify the ways to dusty death and is even equated to it. Imposing the idea of fixity, ice becomes the equivalent of pain, of a bleeding wound, of hate and punishment, each of the connotations embracing the ones previously mentioned. It may be fully charged with symbolic death correlated to illusion, chastity, destruction, or taking part in the elemental fire versus ice opposition it presages Death-in-Life or the reverse process. The animation of ice is apparently a final stage in its evolution and understates surrender and acquiescence to personal annihilation. Thus, the function of this significative element will always be to arrange the whole structure of a literary work by portending Death and/or its manifestations.

\section{References:}

Baker, K. (1972). Hemingway - the writer as artist. Princeton University Press.

Barthes, R. (1989). Lingvistikata na discursa. Narodna kultura. 17.09.1989.

Beer, J. (1974). Ice and spring: Coleridge's imaginative education. Coleridge's Variety. London: Palgrave Macmillan.

Brandon, S. G. (Ed.) (1970). A Dictionary of comparative religion. New York: Charles Scribner's Sons.

Cirlot, J. E. (2006). A Dictionary of symbols. Routledge Dictionaries.

Coleridge, S. (1981). Kubla Khan. In L. Sarieva, \& Y. Stefanova (Eds.), English Romantic poetry, Sofia: Nauka i izkustvo, p. 96.

Coleridge, S. (1981). The ancient Mariner. In L. Sarieva, \& Y. Stefanova (Eds.), English Romantic Poetry, Sofia: Nauka i izkustvo, p.73.

Frost, R. (1972). Fire and ice. In V. Zaharov, \& B. Tomashevskiy (Eds.) An anthology of English and American verse, Moscow: Progress Publishers, p. 508.

Frye, N. (1987). Anatomiya na kritikata. Sofia: Nauka i izkustvo.

Jobes, G. (Ed.) (1961). Dictionary of mythology, folklore and symbols. New York: Scarecrow Press. 
Lotman, Y. (1990). Poetika. Tipologia na kulturata. Sofia: Nauka i izkustvo.

Massinger, P. (1840). Maid of honour. In W. Gifford, The plays of Philip Massinger with notes critical and explanatory, Third Edition, London, p. xxxiii.

Nichev, B. (1986). Osnovi na sravnitelnoto literaturoznanie. Sofia: Nauka i izkustvo.

O’Neill, E. (1994). The iceman cometh. London: Nick Hern Books.

Shakespeare, W. (2016). A midsummer night's dream. In W. Shakespeare, The new Oxford Shakespeare: The complete works, Oxford University Press, p. 1094.

Shakespeare, W. (2016). Cymbeline. In W. Shakespeare, The new Oxford Shakespeare: The complete works, Oxford University Press, p.3011.

Shakespeare, W. (2016). Hamlet. In W. Shakespeare, The new Oxford Shakespeare: The complete works, Oxford University Press, p. 2042.

Shakespeare, W. (2016). Timon of Athens. In W. Shakespeare, The new Oxford Shakespeare: The complete works, Oxford University Press, p.2482.

Shelley, P. B. (1981). Prometheus unbound. In L. Sarieva, \& Y. Stefanova (Eds.), English Romantic poetry, Sofia: Nauka i izkustvo. 155-165.

Spenser, E. (1972). Sonnet XXX. In V. Zaharov, \& B. Tomashevskiy (Eds.) An anthology of English and American verse, Moscow: Progress Publishers, p. 36.

Stoyanov, Ts. (1973). Idei i motivi na otchuzhdenieto v zapadnata literatura. Sofia: Nauka i izkustvo.

Todorov, Ts. (1985). Poetika na prozata. Sofia: Nauka i izkustvo.

Tokarev, S. (ed.) (1980). Токарев, C. Mifi narodov mira, v. I, Moscow: Sovetskaya entsiklopediya. 